\title{
Characterisation of C-type natriuretic peptide receptors in the gill of dogfish Triakis scyllia
}

\author{
H Sakaguchi and Y Takei
}

Laboratory of Physiology, Ocean Research Institute, University of Tokyo, 1-15-1 Minamidai, Nakano-ku, Tokyo 164-8639, Japan

(Requests for offprints should be addressed to H Sakaguchi)

\begin{abstract}
Only C-type natriuretic peptide (CNP) has been identified in primitive elasmobranch fish. CNP is the most conserved molecule in the natriuretic peptide family, suggesting that it is the ancestral type. As a first step to investigating the ancestral type of natriuretic peptide receptors, CNP receptors were characterised in an elasmobranch (dogfish, Triakis scyllia) by radioligandbinding analysis using ${ }^{125} \mathrm{I}-\left[\mathrm{Tyr}^{0}\right]$-dogfish (df)CNP. None of the modifications of the CNP molecule that occur at the time of iodination (addition of a Tyr residue at the $\mathrm{N}$-terminus, introduction of iodine into $\mathrm{Tyr}^{0}$ or oxidation of $\mathrm{Met}^{17}$ ) affect the affinity of dfCNP for the receptors. Neither did oxidation of Met ${ }^{17}$ decrease the ability of CNP to stimulate cGMP production. In the tissues examined, CNP receptors were densest in the gill cells followed by the intestine, interrenal gland and rectal gland, all of which are involved in osmoregulation in elasmobranchs. CNP-stimulated guanylate cyclase (GC) activity was highest in the interrenal gland, intestine, brain and rectal gland, followed by the gill cells. Since the gill cells seem to contain both GC-coupled and uncoupled
\end{abstract}

receptors, this tissue was used to characterise dogfish CNP receptors. Scatchard analysis of the saturation isotherm revealed two classes of binding site: one has a $K_{\mathrm{d}}$ of $24.0 \mathrm{pm}$ and $B_{\max }$ of $59.9 \mathrm{fmol} / \mathrm{mg}$ protein, and the other has low affinity $\left(K_{\mathrm{d}}>1 \mathrm{~nm}\right)$ and high capacity $\left(B_{\max }>200 \mathrm{fmol} / \mathrm{mg}\right.$ protein). The higher-affinity binding sites may represent GC-uncoupled receptors, because C-ANF, a specific ligand for GC-uncoupled receptors, almost completely displaced CNP binding. Affinitylabelling experiments showed that dogfish receptors have molecular masses of about 90, 170 and $340 \mathrm{kDa}$, and CNP binding to the former two receptors is inhibited by C-ANF. After reduction with 2-mercaptoethanol, most $170 \mathrm{kDa}$ labelling was shifted to $90 \mathrm{kDa}$. It is concluded that GC-uncoupled receptors in the dogfish gill have higher molecular mass than those of mammals and eel (about $65 \mathrm{kDa}$ ), and are present mostly as monomers even in non-reducing conditions. However, a small population of GC-coupled receptors is also present, as demonstrated by an increase in cGMP production.

Journal of Endocrinology (1998) 156, 127-134

\section{Introduction}

A-type (atrial) natriuretic peptide (ANP) was first discovered as a cardiac hormone with potent diuretic and natriuretic properties (de Bold 1985). It is now known that ANP, B-type (brain) natriuretic peptide (BNP) and C-type natriuretic peptide (CNP) function as a family to maintain volume and pressure homoeostasis. In teleost fish, a new type named ventricular natriuretic peptide (VNP) has been identified (Hagiwara et al. 1995). ANP, BNP and VNP are all cardiac hormones circulating in blood, while CNP is basically a paracrine factor in the brain and other peripheral tissues (Espiner 1994). In elasmobranch fish, however, only CNP and its mRNA have been detected in the heart as well as the brain (Suzuki et al. 1991, Schofield et al. 1991), and its concentrations in the heart and plasma are even higher than those of ANP, BNP and VNP in mammals and teleost fish (Suzuki et al. 1994). It seems therefore that CNP is the sole natriuretic peptide in elasmobranchs, and it works not only as a paracrine factor but also as a circulating hormone. Thus CNP is considered to be an ancestral form of the natriuretic peptide family.

Natriuretic peptide receptors (NPRs) are also identified in selected vertebrate species (for a review, see AnandSrivastava \& Trachte 1993). NPR-A and NPR-B are membrane-bound guanylate cyclase (GC) with a molecular mass of $140 \mathrm{kDa}$, and thus utilise cGMP as an intracellular messenger. NPR-C and NPR-D have a molecular mass of $65 \mathrm{kDa}$ and their intracellular messenger is as yet undetermined. NPR-D has only been identified in the eel (Kashiwagi et al. 1995). NPR-A, NPR-B and NPR-D are present as tetramers, but NPR-C is a dimeric receptor. ANP and BNP are selective ligands for NPR-A and CNP for NPR-B, while all natriuretic peptides exhibit similar affinity for NPR-C and NPR-D.

For experiments designed to try to understand the complicated natriuretic peptide system, dogfish is a useful material because only CNP has been identified in this 
species. Since CNP is thought to be an ancestral form of the natriuretic peptide family, it is of interest to examine which types of receptor are present in the dogfish. To pursue this aim therefore we characterised NPRs in the dogfish Triakis scyllia using radioligand-binding studies in combination with cGMP assay and affinity labelling.

\section{Materials and Methods}

\section{Drugs}

Dogfish CNP (dfCNP), $\left[\mathrm{Tyr}^{0}\right]$-dfCNP, dogfish angiotensin II (dfANGII), C-ANF (rat des[Gln ${ }^{18}, \mathrm{Ser}^{19}, \mathrm{Gly}^{20}$, $\left.\left.\mathrm{Leu}^{21}, \mathrm{Gly}^{22}\right]-\mathrm{ANP}(4-23)-\mathrm{NH}_{2}\right)$, pepstatin and leupeptin were obtained from Peptide Institute Inc. (Osaka, Japan). A protein molecular mass marker kit was purchased from Boehringer-Mannheim (Mannheim, Germany). Other reagents were from Wako Pure Chemical Industries Ltd (Osaka, Japan) or Sigma Chemical Co. (St Louis, MO, USA) unless otherwise specified. $\mathrm{Na}^{125} \mathrm{I}(72 \mathrm{TBq} / \mathrm{mmol})$ was purchased from Amersham International (Amersham, Bucks, UK). ${ }^{125} \mathrm{I}-\left[\mathrm{Tyr}^{0}\right]-\mathrm{dfCNP}$ was prepared by the lactoperoxidase method, and purified by reverse-phase HPLC on an ODS-120T column $(4.6 \times 250 \mathrm{~mm}$; Tosoh, Tokyo, Japan) with a linear gradient of $\mathrm{CH}_{3} \mathrm{CN}$ from 15 to $60 \%$ for $60 \mathrm{~min}$ (Suzuki et al. 1994). Since the methionine residue at position 17 of dfCNP was oxidised during the iodination, $\left[\mathrm{I}-\mathrm{Tyr}^{0}, \mathrm{Met}^{17}(\mathrm{O})\right]$-dfCNP was prepared as above using unlabelled $\mathrm{NaI}$ to test its ability for binding and stimulating cGMP production.

\section{Preparation of membrane fraction}

Dogfish (Triakis scyllia) of either sex caught in June 1996 at Koajiro Bay, Kanagawa, were purchased from fishermen, and kept in an aquarium with running seawater at Misaki Marine Biological Station, University of Tokyo, for more than 1 week before use. They weighed $0 \cdot 8-2 \cdot 5 \mathrm{~kg}$ at the time of experimentation. Membrane fractions were prepared from various tissues as described previously (Mishina \& Takei 1997). The dogfish were anaesthetised by immersion in $1 \%$ tricaine methanesulphonate for $10 \mathrm{~min}$ and the heart was exposed. After collection of blood, any remaining blood was removed by perfusing $50 \mathrm{ml}$ dogfish saline $(240 \mathrm{~mm} \mathrm{NaCl}$ and $423 \mathrm{~mm}$ urea) into the conus arteriosus after puncture of the sinus venosus. Tissues were quickly removed and frozen in liquid nitrogen. The gill cells were scraped from the gill arches and also frozen in liquid nitrogen until use. On the day of membrane preparation, the thawed gill cells were mixed thoroughly with 5 volumes of dogfish saline, filtered through a nylon mesh (pore size $40 \mu \mathrm{m}$ ) to remove contaminated blood vessels, and centrifuged at $800 \mathrm{~g}$ for $10 \mathrm{~min}$ to collect the cells. These procedures were repeated twice to remove the mucus secreted from the cell. The pellets of gill cells, or diced other tissues, were homogenised in 8 volumes of buffer A (250 mm sucrose, $10 \mathrm{~mm}$ disodium EDTA, $50 \mathrm{~mm}$ Tris-HCl, $\mathrm{pH} 7 \cdot 2$ ) with a Polytron homogeniser at setting 6 for $30 \mathrm{~s}$. The homogenates were centrifuged at $12000 \mathrm{~g}$ for $20 \mathrm{~min}$, and the supernatants were centrifuged again at $57000 \boldsymbol{g}$ for $30 \mathrm{~min}$. The pellets were resuspended in 5 volumes of buffer $\mathrm{A}$, and centrifuged at $57000 \mathrm{~g}$ for $30 \mathrm{~min}$. The pellets were suspended in buffer B (50 mm Tris-HCl, $5 \mathrm{~mm} \mathrm{MgCl}_{2}, 125 \mathrm{~mm} \mathrm{NaCl}$, $\mathrm{pH} 7 \cdot 2$ ), and the protein concentration was determined by using a protein assay kit (Bio-Rad, Richmond, CA, USA) after treatment with $1 \mathrm{~m} \mathrm{NaOH}$. The membrane fractions thus prepared were stored in liquid nitrogen until use.

\section{Binding assay}

For the binding assay, $10^{-10} \mathrm{M}^{125} \mathrm{I}-\left[\mathrm{Tyr}^{0}\right]-\mathrm{dfCNP}$ and $25 \mu \mathrm{g}$ membrane fraction were incubated in $100 \mu \mathrm{l}$ buffer $\mathrm{B}$ containing $10^{-4} \mathrm{M}$ EGTA, $10^{-4} \mathrm{M}$ phenanthroline, $10^{-5} \mathrm{M}$ phosphoramidon and $2 \mathrm{mg} / \mathrm{ml} \mathrm{BSA}$ for $120 \mathrm{~min}$ at $25{ }^{\circ} \mathrm{C}$ unless otherwise stated. It was confirmed by HPLC analysis that free and bound ${ }^{125} \mathrm{I}-\left[\mathrm{Tyr}^{0}\right]-$ dfCNP were not metabolised after incubation under these conditions (Mishina \& Takei 1997). After incubation, $1 \mathrm{ml}$ ice-cold buffer B was added to each tube to terminate the reaction. The aliquots were then centrifuged at $14000 \mathrm{~g}$ for $5 \mathrm{~min}$ at $4{ }^{\circ} \mathrm{C}$ and radioactivity in the pellets was counted with a Riastar $\gamma$-counting system (Packard Instrument Co., Meriden, CT, USA). Specific binding was defined as the difference between the amount of radioligand bound in the absence and presence of $10^{-6} \mathrm{M}$ dfCNP. The time course of binding was examined at 4 , 18,25 and $37^{\circ} \mathrm{C}$. The saturation experiment was performed at $2 \times 10^{-11}-2 \times 10^{-7} \mathrm{M}^{125} \mathrm{I}^{-\left[\mathrm{Tyr}^{0}\right] \text {-dfCNP to }}$ determine the affinity $\left(K_{\mathrm{d}}\right)$ and binding capacity $\left(B_{\max }\right)$ of the receptors. To examine the specificity of the receptors, displacement experiments were performed with dfCNP, $\left[\mathrm{Tyr}^{0}\right]-\mathrm{dfCNP},\left[\mathrm{I}-\mathrm{Tyr}^{0}, \mathrm{Met}^{17}(\mathrm{O})\right]-\mathrm{dfCNP}$ and C-ANF at a concentration of $10^{-12}-10^{-6} \mathrm{M}$. The acquired data were analysed using the LIGAND program (Munson \& Rodbard 1980) to calculate the binding parameters.

\section{Assay for cGMP production}

GC activity was determined as described previously (Mishina \& Takei 1997). Membrane fraction prepared from each tissue $(30 \mu \mathrm{g})$ was incubated at $25{ }^{\circ} \mathrm{C}$ for $10 \mathrm{~min}$ in $80 \mu \mathrm{l} 50 \mathrm{~mm}$ Tris- $\mathrm{HCl}$ buffer, $\mathrm{pH} 7 \cdot 6$, containing $1 \mathrm{mg} / \mathrm{ml}$ BSA, $0.5 \mathrm{~mm}$ isobutyl-1-methylxanthine, $15 \mathrm{~mm}$ phosphocreatine and $31.25 \mathrm{U} / \mathrm{ml}$ creatine kinase. Then $1 \mathrm{~mm}$ GTP, $4 \mathrm{~mm} \mathrm{MnCl}_{2}$ and 0 or $10^{-6} \mathrm{M}$ dfCNP were added to the mixture to adjust the final volume to $100 \mu \mathrm{l}$, and the mixture was incubated for a further $10 \mathrm{~min}$ at $25^{\circ} \mathrm{C}$. The reaction was stopped by adding $900 \mu \mathrm{l}$ $50 \mathrm{~mm}$ ammonium acetate buffer, $\mathrm{pH} 4 \cdot 0$, followed by boiling for $3 \mathrm{~min}$. The suspension was centrifuged at 
$14000 \mathrm{~g}$ for $5 \mathrm{~min}$ at $4{ }^{\circ} \mathrm{C}$, and cGMP concentrations in the supernatant were determined by RIA using a cGMP assay kit (Yamasa, Tokyo, Japan) according to the manufacturer's protocol.

\section{Affinity labelling}

The membrane fraction of gill cells $(30 \mu \mathrm{g})$ in buffer B was centrifuged at $14000 \mathrm{~g}$ for $10 \mathrm{~min}$ at $4{ }^{\circ} \mathrm{C}$, and the pellet was resuspended in $50 \mu \mathrm{l} 20 \mathrm{~mm}$ phosphate buffer, $\mathrm{pH} 7 \cdot 4$, containing $130 \mathrm{~mm} \mathrm{NaCl}, 1 \mathrm{~mm}$ EDTA, $1 \mathrm{mg} / \mathrm{ml}$ lysozyme, $0 \cdot 2 \mathrm{~mm}$ phenylmethylsulphonyl fluoride, $10 \mu \mathrm{g} / \mathrm{ml}$ leupeptin and $10 \mu \mathrm{g} / \mathrm{ml}$ pepstatin. After the addition of $50 \mu \mathrm{l}{ }^{125} \mathrm{I}_{-}\left[\mathrm{Tyr}^{0}\right]$-dfCNP $\left(3 \times 10^{-10} \mathrm{M}\right)$, the reaction mixture was incubated for $120 \mathrm{~min}$ at $25^{\circ} \mathrm{C}$ in the absence or presence of $10^{-6} \mathrm{M}$ unlabelled dfCNP or C-ANF. The bound ${ }^{125} \mathrm{I}-\left[\mathrm{Tyr}^{0}\right]-\mathrm{dfCNP}$ was cross-linked to the receptors by incubation with $2 \mathrm{~mm}$ disuccinimidyl suberate (Pierce Chemical, Rockford, IL, USA) for $20 \mathrm{~min}$ at $25^{\circ} \mathrm{C}$. The reaction was terminated by adding $20 \mu \mathrm{l} 2 \mathrm{M}$ ammonium acetate. The mixture was then centrifuged at $14000 \mathrm{~g}$ for $5 \mathrm{~min}$ at room temperature, and the pellet was suspended in $50 \mu \mathrm{l}$ loading buffer $(650 \mathrm{~mm}$ Tris- $\mathrm{HCl}$, $\mathrm{pH} 6 \cdot 8$, containing $10 \%(\mathrm{w} / \mathrm{v})$ glycerol, $1 \%$ SDS and $0.1 \mathrm{mg} / \mathrm{ml}$ bromophenol blue with or without $1 \%$ 2-mercaptoethanol) and boiled for $5 \mathrm{~min}$. The mixture was centrifuged at $14000 \mathrm{~g}$ for $5 \mathrm{~min}$, and then $30 \mu \mathrm{l}$ supernatant was electrophoresed on a $5.0 \%$ polyacrylamide slab gel. The proteins in the gel were fixed by incubation in $10 \%$ acetic acid and $25 \%$ methanol, and visualised by Coomasie brilliant blue staining. The dried slab gels were exposed to an imaging plate for $48 \mathrm{~h}$ for analysis in a BAS-1000 Mac system (Fuji Photo Film Co., Tokyo, Japan). The gel was later exposed to Kodak BioMax MS films with BioMax MS intensifying screen (Eastman Kodak, New Heaven, CT, USA) at $-80{ }^{\circ} \mathrm{C}$ for 1 week, and the film was developed in Kodak D-19 developer.

\section{Results}

We first determined the assay conditions for ${ }^{125} \mathrm{I}-\left[\mathrm{Tyr}^{0}\right]-$ dfCNP binding using the gill membrane fraction. Specific binding of ${ }^{125} \mathrm{I}-\left[\mathrm{Tyr}^{0}\right]-\mathrm{dfCNP}$ increased linearly according to the amount of membrane protein in the incubation mixture, reaching a plateau at $80 \mu \mathrm{g}$ (Fig. 1a). Binding was more rapid at higher temperatures, but the rate was not increased further above $25^{\circ} \mathrm{C}$ (Fig. 1b). Equilibrium binding was attained in $60 \mathrm{~min}$ at $25^{\circ} \mathrm{C}$ and was maintained for more than $180 \mathrm{~min}$. Therefore the incubation was performed with $25 \mu \mathrm{g}$ protein at $25^{\circ} \mathrm{C}$ for $120 \mathrm{~min}$ in subsequent experiments.

Figure 2 shows the amount of specific CNP binding in dogfish tissues. Binding was greatest in the gill followed by the intestine, interrenal gland and rectal gland. The liver, heart, kidney and brain also showed significant binding, but the amount was much smaller.
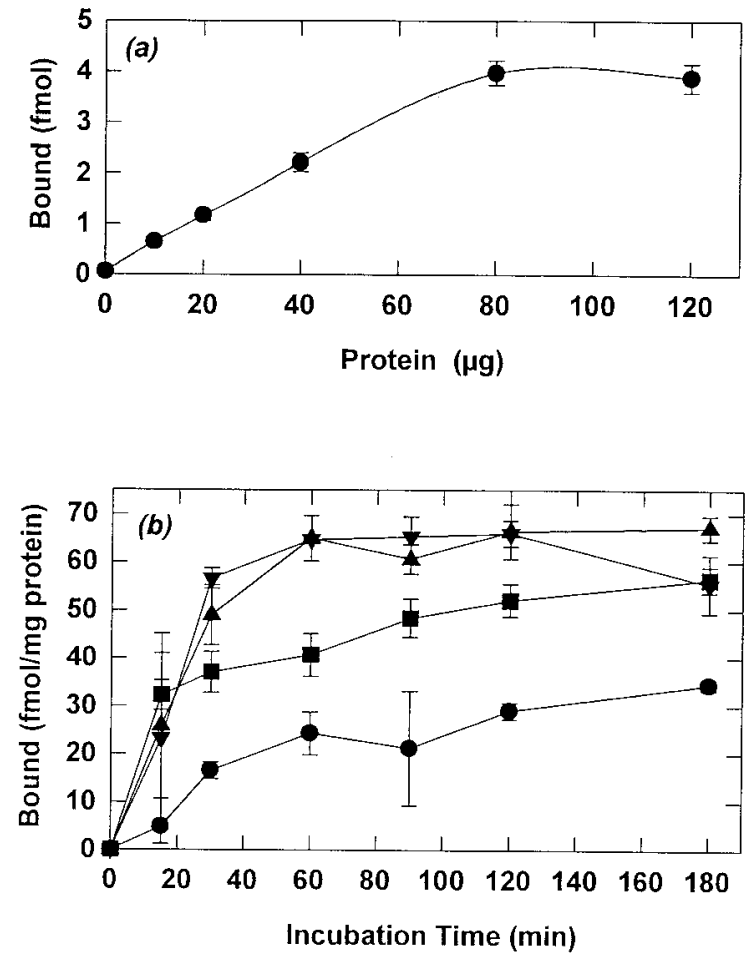

Figure 1 (a) Relationship between ${ }^{125} \mathrm{I}-\left[\mathrm{Tyr}^{\mathrm{O}}\right]$-dfCNP binding and membrane protein, and (b) time course of ${ }^{125} \mathrm{I}-\left[\mathrm{Tyr}^{\mathrm{O}}{ }^{\mathrm{O}}\right.$-dfCNP binding at different temperatures $\left(\bullet, 4{ }^{\circ} \mathrm{C} ; \boldsymbol{\square}, 18^{\circ} \mathrm{C} ; \boldsymbol{\Lambda}, 25^{\circ} \mathrm{C}\right.$; $\boldsymbol{\nabla}, 37^{\circ} \mathrm{C}$ ) in dogfish gills. Values are means of three measurements of one membrane preparation. Vertical bars represent S.E.M.

cGMP production was markedly stimulated by CNP in the intestine, brain, interrenal gland and rectal gland, and less so in the gill, kidney and liver (Fig. 3). C-ANF was not effective even at $10^{-6} \mathrm{M}$, but iodinated and methionine-oxidised $\left[\mathrm{Tyr}^{0}\right]-\mathrm{dfCNP},\left[\mathrm{I}-\mathrm{Tyr}^{0}, \mathrm{Met}^{17}(\mathrm{O})\right]-$ dfCNP was as effective as dfCNP in stimulating cGMP production in the gill membrane (data not shown).

A saturation isotherm showed that CNP binding was saturated initially between $10^{-9}$ and $10^{-8} \mathrm{M}$, but binding increased again above $10^{-8} \mathrm{M}$ and reached a plateau at $5 \times 10^{-8} \mathrm{M}$ (Fig. $4 a$ ). Scatchard analysis demonstrated two classes of binding site (Fig. $4 b$ ): $K_{\mathrm{d}}$ and $B_{\max }$ for the high-affinity site were respectively $24 \cdot 0 \pm 5 \cdot 8 \mathrm{pM}$ and $59 \cdot 9 \pm 12 \cdot 8 \mathrm{fmol} / \mathrm{mg}$ protein, and higher than $1 \mathrm{nM}$ and more than $200 \mathrm{fmol} / \mathrm{mg}$ protein for the other site.

As shown in Fig. 5, CNP binding to the gill membrane was displaced in a concentration-dependent manner by unlabelled dfCNP and C-ANF but not by ANGII, demonstrating specificity for the natriuretic peptides. $\left[\mathrm{I}-\mathrm{Tyr}^{0}, \mathrm{Met}^{17}(\mathrm{O})\right]-\mathrm{dfCNP}$ had an affinity similar to that of dfCNP. Scatchard analysis of the displacement experiment revealed a single class of binding site with $K_{\mathrm{d}}$ and $B_{\max }$ of $116.3 \mathrm{pM}$ and $69 \cdot 4 \mathrm{fmol} / \mathrm{mg}$ protein respectively. Since the ${ }^{125} \mathrm{I}-\left[\mathrm{Tyr}^{0}\right]-\mathrm{dfCNP}$ concentration used in this 


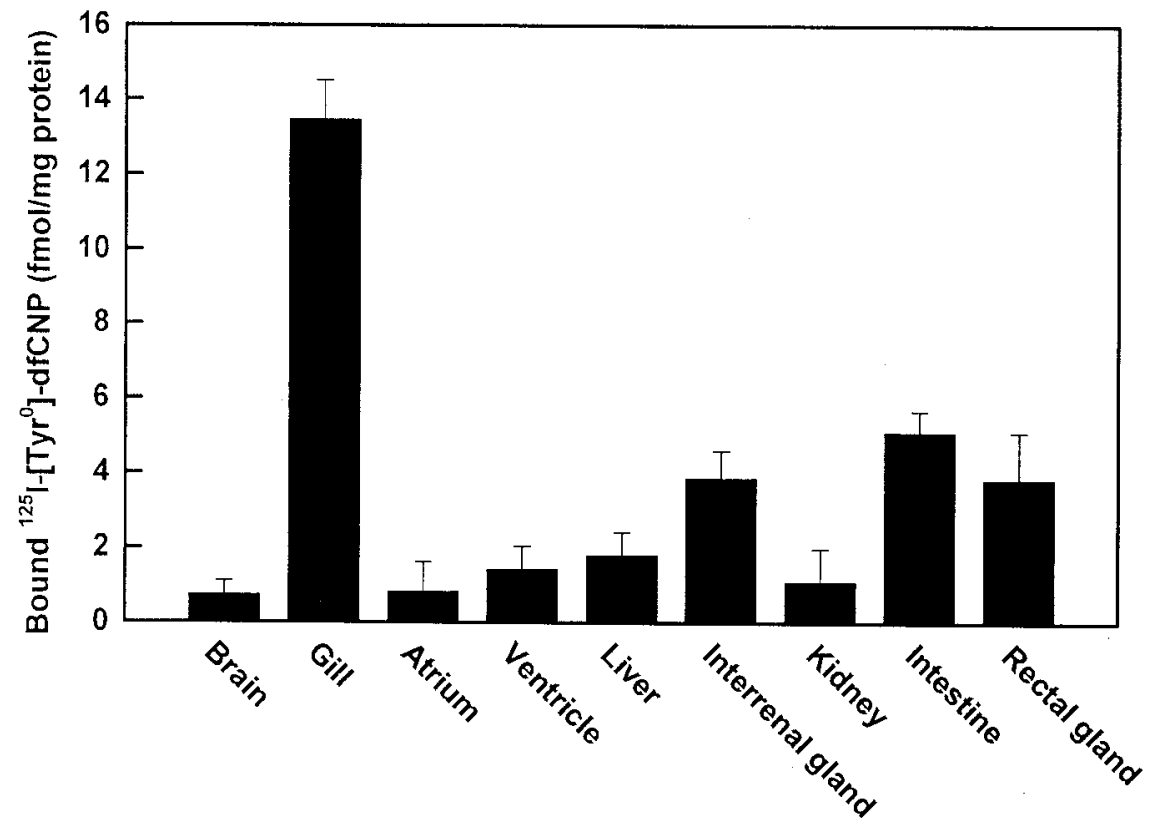

Figure 2 Specific ${ }^{125} \mathrm{I}-\left[\mathrm{Tyr}^{\mathrm{O}}\right]$-dfCNP-binding sites in various dogfish tissues. Each result represents the mean of three experiments using three membrane preparations for all tissue membranes except interrenal gland for which one preparation was used. Each membrane was prepared from two animals. Interrenal gland membrane was prepared from 12 animals. Vertical bars represent S.E.M.

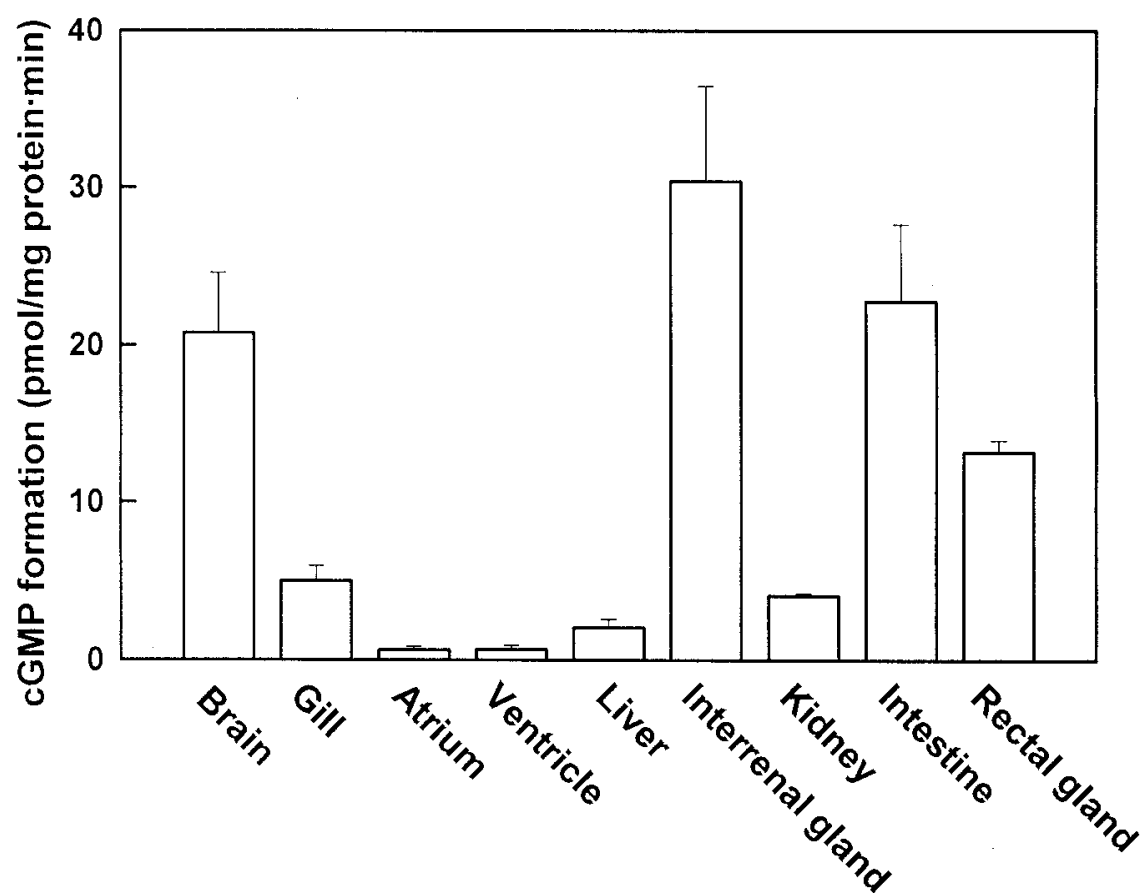

Figure 3 CNP-stimulated GC activity in various dogfish tissues. Each value represents the mean of three experiments using the membrane preparations as described in Fig. 2. Vertical bars show S.E.M. 

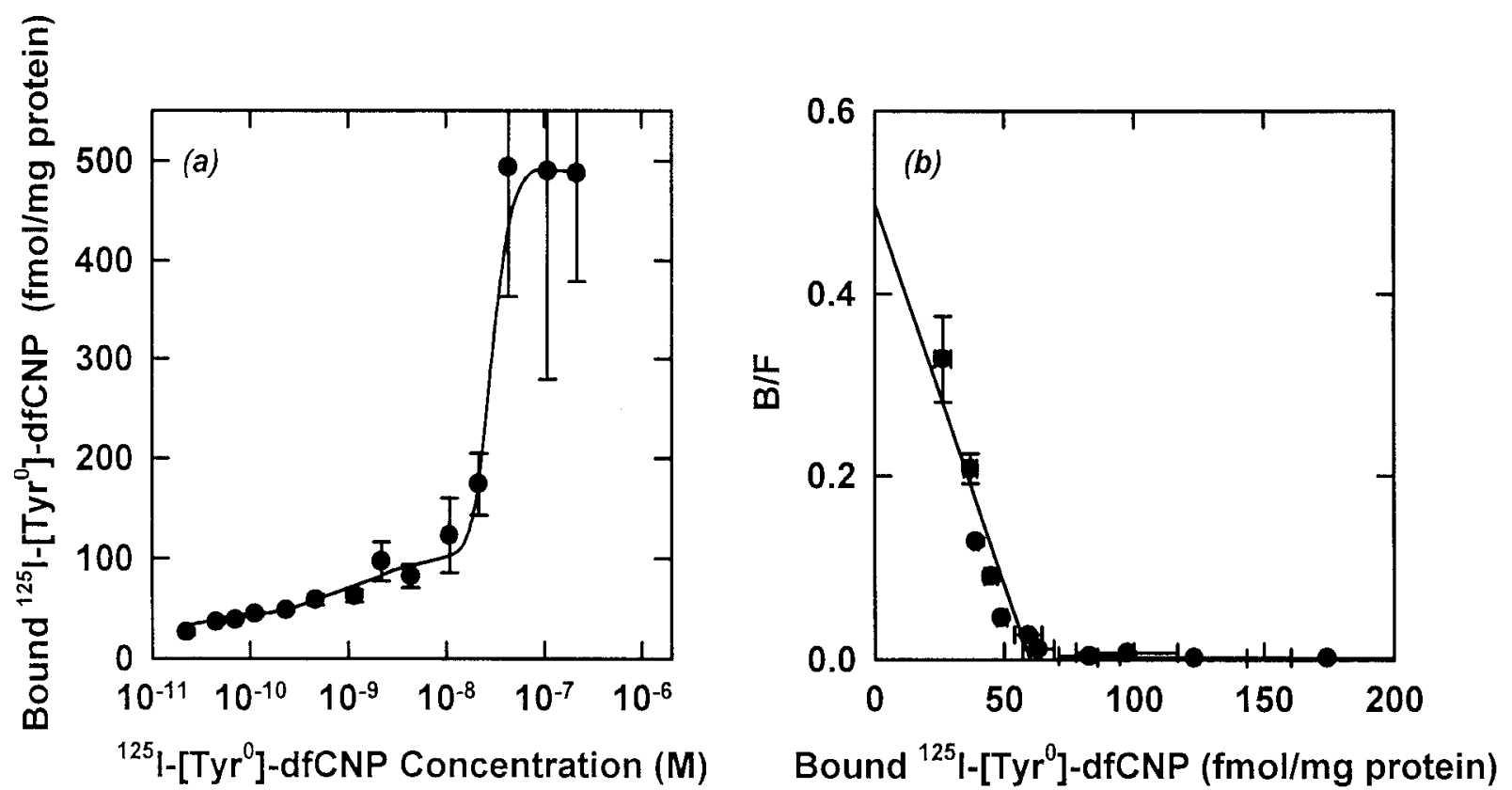

Figure 4 (a) Saturation isotherm of ${ }^{125} \mathrm{I}-\left[\mathrm{Tyr}^{\mathrm{O}}\right]$-dfCNP binding to the membrane fraction of dogfish gill (mean \pm S.E.M.). (b) Scatchard plot of the isotherm.

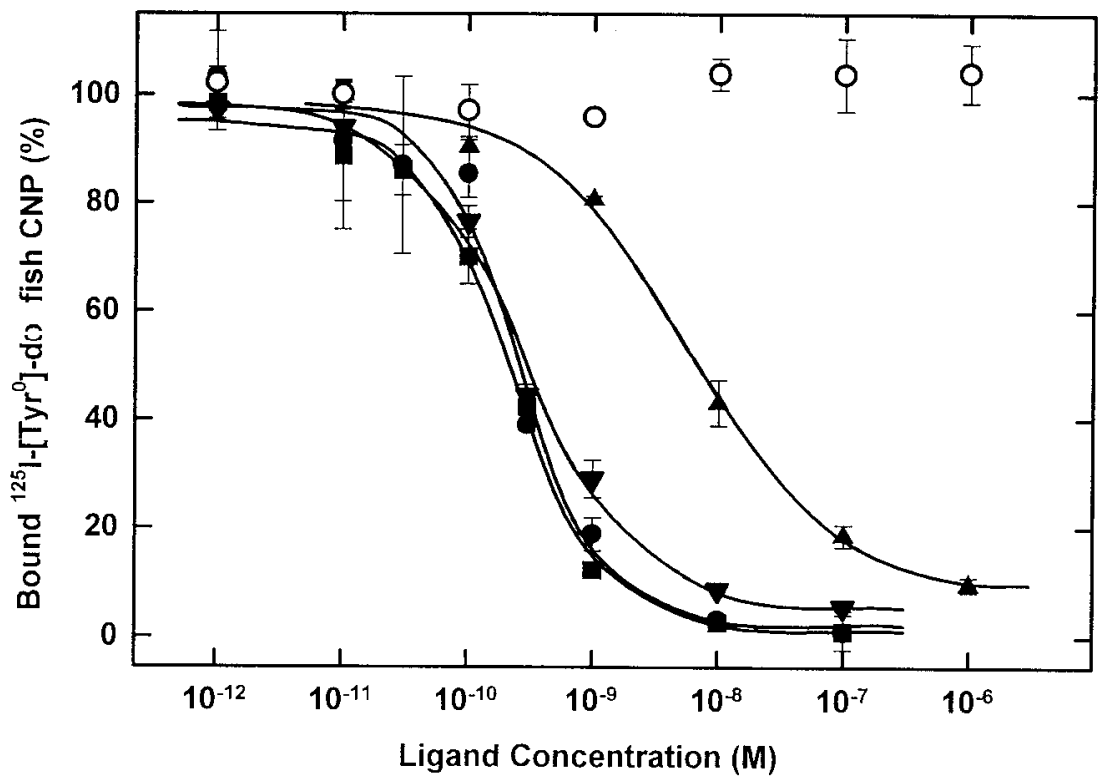

Figure 5 Displacement of ${ }^{125} \mathrm{I}-\left[\mathrm{Tyr}^{\mathrm{O}}\right]-\operatorname{dfCNP}$ by $\operatorname{dfCNP}(\boldsymbol{\bullet}),\left[\operatorname{Tyr}^{\mathrm{O}}\right]-\operatorname{dfCNP}(\mathbf{\square})$,

$\left[\mathrm{I}-\mathrm{Tyr}^{\mathrm{O}}, \mathrm{Met}^{17}(\mathrm{O})\right]-\mathrm{dfCNP}(\boldsymbol{\nabla}), \mathrm{C}-\mathrm{ANF}(\boldsymbol{\Delta})$ and dfANGII $(O)$. Each point is the mean \pm S.E. of three experiments using the three membrane fractions described in the Fig. 2 legend.

experiment was $10^{-10} \mathrm{M}$, ligand bound exclusively to the high-affinity site, as demonstrated by the saturation binding experiment.

Affinity labelling with $3 \times 10^{-10} \mathrm{M}{ }^{125} \mathrm{I}-\left[\mathrm{Tyr}^{0}\right]-$ dfCNP revealed that the receptor proteins had molecular masses of approximately 90,170 and $340 \mathrm{kDa}$ in both non-reducing and reducing conditions (Fig. 6). Binding to the 340 and $170 \mathrm{kDa}$ proteins was displaced almost completely by $10^{-6} \mathrm{M}$ dfCNP, but some signal remained with the $90 \mathrm{kDa}$ protein. C-ANF also displaced dfCNP binding similarly. After reduction with 2-mercaptoethanol, the signal became much weaker for 


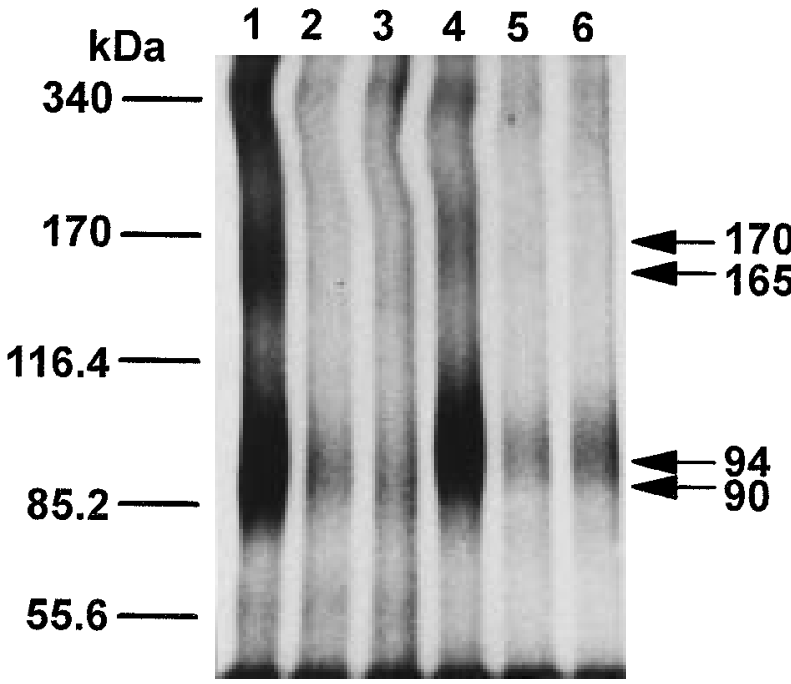

Figure 6 Affinity labelling of dogfish CNP receptors using $3 \times 10^{-10} \mathrm{M}^{125} \mathrm{I}-\left[\mathrm{Tyr}^{\mathrm{O}}\right]$-dfCNP. The CNP receptors were labelled in the absence (lanes 1 and 4 ) or presence of $1 \mu \mathrm{M}$ unlabelled dfCNP (lanes 2 and 5) or C-ANF (lanes 3 and 6). The samples were analysed by SDS/PAGE under non-reducing conditions (lanes 1, 2 and 3) or after reduction with 2-mercaptoethanol (lanes 4, 5 and 6). This experiment was carried out twice using two separate membrane preparations.

the 340 and $170 \mathrm{kDa}$ proteins, but became stronger for the $90 \mathrm{kDa}$ protein.

\section{Discussion}

The present study demonstrates two types of CNP receptor, GC-coupled and uncoupled, in the gill cells of the dogfish Triakis scyllia. The population of GCuncoupled receptors was more than $90 \%$, as demonstrated by displacement with C-ANF, a specific ligand for GCuncoupled receptors (Maack et al. 1987, Takashima et al. 1995, Kashiwagi et al. 1995), and by the weak stimulation of cGMP production by dfCNP. Similar results have recently been reported in another dogfish, Squalus acanthias (Donald et al. 1997). The function of dense GCuncoupled receptors in the dogfish gill may be to regulate plasma CNP titre, as has been suggested for the trout (Olson \& Duff 1993) and eel (Kaiya \& Takei 1996). Most of the GC-uncoupled receptors may be homodimeric NPR-C, as observed in mammalian lung (Shimonaka et al. 1987) and teleost gill (Olson \& Duff 1993, Donald et al. 1994, Mishina \& Takei 1997), because most $170 \mathrm{kDa}$ receptors are converted to $90 \mathrm{kDa}$ after reduction with 2-mercaptoethanol. The presence of tetrameric NPR-D was not excluded in the dogfish gill, but its population is minor as shown in eel gill (Mishina \& Takei 1997).

The affinity labelling experiment revealed that dogfish NPR-C-like receptors exist not only as homodimers or homotetramers but also as monomers under non-reducing conditions, and the molecular mass of the monomer $(\sim 90 \mathrm{kDa})$ is higher than that of NPR-C or NPR-D ( $\sim 65 \mathrm{kDa}$; Lowe et al. 1990, Takashima et al. 1995, Kashiwagi et al. 1995). The molecular mass of NPR-Clike receptors in Squalus acanthias is also higher (Donald et al. 1997). Mutation analysis of NPR-C showed that formation of a dimeric structure is not essential for ligand binding (Itakura et al. 1993). In fact, dfCNP binds to the monomeric dogfish NPR-C-like receptors. It is possible that the $90 \mathrm{kDa}$ receptors are a deletion mutant of NPR-B which lacks GC activity identified in the rat (Ohyama et al. 1992). However, Donald et al. (1997) amplified the PCR product with NPR-C-specific primers. cDNA cloning of the full sequence of the dogfish receptors will give a definite answer to this question.

The saturation isotherm revealed that binding increased above $10^{-8} \mathrm{M}$ dfCNP. The Scatchard analysis also identified two classes of binding site, one with a $K_{\mathrm{d}}$ of $24 \mathrm{pm}$ and $B_{\max }$ of $59.9 \mathrm{fmol} / \mathrm{mg}$ protein, and the other with a very low affinity and high capacity. Since all binding experiments including displacement experiments and affinity labelling were performed with $10^{-10} \mathrm{M}$ or $3 \times 10^{-10} \mathrm{M}{ }^{125} \mathrm{I}$-dfCNP, the labelled ligand did not bind to these low-affinity binding sites. Therefore the binding characteristics obtained in this study apply only to the high-affinity site, which satisfies criteria for identification of receptors, i.e. specificity, saturability and high affinity. These characteristics are those of NPR-C-like receptors, and it is possible that a small number of GC-coupled receptors present in the dogfish gill may have similar affinity or may be too minor to be detected by Scatchard analysis.

The $K_{\mathrm{d}}$ value, which represents the ligand concentration at which half of the ligand occupies the receptors, was $24 \mathrm{pm}$ as shown in this study, while plasma CNP concentration in the dogfish was measured as $1.97 \mathrm{nM}$ (Suzuki et al. 1994). The HPLC analysis showed that most circulating CNP in the dogfish plasma was prohormone. It is not known whether dogfish proCNP has an affinity similar to that of dfCNP-22 for the dogfish receptors, but, if so, all the receptors are occupied by the circulating proCNP. Therefore it is likely that proCNP is enzymically converted to mature forms in the circulation and generates biological responses only when proCNP titre increases above a certain level. In this respect, it seems reasonable to speculate that the CNP-binding protein with low affinity detected in the saturation experiment is a membranebound proCNP-processing enzyme, which cleaves proCNP when its concentration increases above about $10 \mathrm{~nm}\left(10^{-8} \mathrm{M}\right)$.

It is of interest to note that modifications of the dfCNP molecule, i.e. addition of tyrosine residues at the $\mathrm{N}$-terminus, oxidation of $\mathrm{Met}^{17}$, introduction of iodine into $\mathrm{Tyr}^{\circ}$, did not change the affinity of dfCNP for its receptors, nor decrease its ability to stimulate cGMP 
accumulation. These results show that the $\mathrm{N}$-terminus and the methionine residue in the intramolecular ring of dfCNP are not important for expression of biological activity. This is surprising because oxidation of $\mathrm{Met}^{13}$ in the intramolecular ring of rat ANP abolishes its biological activity (Watanabe et al. 1988). The low ligand selectivity of dogfish receptors may be explained in part by the presence of only CNP in this species.

In addition to the gill, significant CNP binding and stimulation of cGMP production were noted in the intestine, interrenal gland and rectal gland, indicating biological actions in these tissues. Significant CNP binding was also noted in the liver, but the binding may be due to NPR-C because of the lack of cGMP production in these tissues. CNP stimulated cGMP production significantly in the brain, although CNP-binding capacity was low. Since ANP inhibits drinking and neurohypophyseal hormone secretion (Brenner et al. 1990), CNP may also act on the brain to modulate these processes.

Since the plasma osmolality of marine teleost fish is almost one-third of that of seawater, these fish drink copiously to compensate for water lost osmotically through the body surfaces (Evans 1993). Thus intestinal absorption of ingested water is essential for teleost osmoregulation. However, the plasma osmolality of elasmobranchs is slightly hyperosmotic compared with seawater because of the accumulation of urea and trimethylamine oxide in the plasma. Therefore the contribution of the intestine to elasmobranch osmoregulation may not be so large. ANP potently inhibits intestinal ion and water transport in mammals and teleost fish (O'Grady et al. 1985, Matsushita et al. 1991, Ando et al. 1992, Loretz 1996). The presence of dense GC-coupled CNP receptors in the dogfish intestine, suggested in this study, is intriguing.

Dogfish interrenal gland secretes $1 \alpha$-hydroxycorticosterone $(1 \alpha-\mathrm{OHB})$ as a principal mineralocorticosteroid. The secretion of $1 \alpha-\mathrm{OHB}$ is stimulated by ANGII in Scyliorhinus canicula (Hazon \& Henderson 1985), and dense ANGII receptors were identified in Triakis interrenal gland (Tierney et al. 1997). ANGII has been shown to stimulate mineralocorticoid secretion in species from teleost fish to mammals (see Kobayashi \& Takei 1996), and ANP is known to modify its secretion in these vertebrate species (Racz et al. 1985, Lihrmann et al. 1988, Arnold-Reed \& Balment 1991). Thus it is likely that CNP modulates $1 \alpha-\mathrm{OHB}$ secretion in the dogfish.

It has been reported that CNP promotes rectal gland secretion in the spiny dogfish, Squalus acanthias (Solomon et al. 1992). In this species, the action of CNP seems to be mediated by vasoactive intestinal peptide (Silva et al. 1996). The presence of GC-coupled receptors found in the present study also suggests CNP action on the Triakis rectal gland. In the rectal gland of spiny dogfish, two types of receptor have been identified, GC-coupled and uncoupled receptors, using porcine CNP, Squalus CNP, rat ANP, porcine BNP and C-ANF (Gunning et al. 1993).
The competitive binding assay revealed that half of the receptors were GC-coupled. The detection of GCcoupled and uncoupled receptors in Triakis rectal gland fits well with this result.

The substantial osmotic influx of water across the gills of elasmobranchs because of the slightly hypertonic body fluid is balanced by copious glomerular filtration, which approaches that of freshwater teleosts (Evans 1993). Although CNP binding was found to be low in this study, CNP-stimulated cGMP production was significant in the kidney. The relatively low receptor population may be due to the topical localisation of receptors in the glomerulus relative to the large dogfish kidney. Dense ANP receptors have been identified in the glomeruli of several vertebrate species by autoradiography (Bianchi et al. 1985, Kloas \& Hanke 1992, Sakaguchi et al. 1996).

It is believed that CNP is the sole natriuretic peptide in elasmoblanchs, the most primitive vertebrate species in which natriuretic peptides have been identified. This leads to the assumption that the ancestral form of natriuretic receptors is NPR-B because its specific ligand is CNP. However, the present study also demonstrated the presence of GC-uncoupled receptors in the dogfish gill. It is not known whether this type is NPR-C or a deletion mutant of GC-coupled receptors. Clarification of the identity of the ancestral gene of NPRs awaits cDNA cloning of the elasmobranch CNP receptor.

\section{Acknowledgements}

We are grateful to the staff of Misaki Marine Biological Station, University of Tokyo for supplying dogfish and Dr. Neil Hazon, Dr. Mary Tierney and Miss Lynne Birrell of University of St Andrews for helping to collect dogfish tissues. This work was supported by a Research Fellowship from the Japan Society for the Promotion of Science (199504689) to H S, Grants-in-Aid for Scientific Research from the Ministry of Education, Science and Culture of Japan (08640843) to Y T, and the Fisheries Agency of Japan.

\section{References}

Anand-Srivastava MB \& Trachte GJ 1993 Atrial natriuretic factor receptors and signal transduction mechanisms. Pharmacological Reviews 45 455-497.

Ando M, Kondo K \& Takei Y 1992 Effects of eel atrial natriuretic peptide on $\mathrm{NaCl}$ and water transport across the intestine of the seawater eel. Journal of Comparative Physiology B 162 436-439.

Arnold-Reed DE \& Balment RJ 1991 Atrial natriuretic factor stimulates in vivo and in vitro secretion of cortisol in teleosts. Journal of Endocrinology 128 R17-R20.

Bianchi C, Gutkowska J, Thibault G, Garcia R, Genest J \& Cantin M 1985 Radioautographic localization of ${ }^{125} \mathrm{I}$-atrial natriuretic factor (ANF) in rat tissues. Histochemistry 82 441-452.

de Bold AJ 1985 Atrial natriuretic factor: a hormone produced by the heart. Science $230767-770$. 
Brenner BM, Ballermann BJ, Gunning ME \& Zeidel ML 1990 Diverse biological actions of atrial natriuretic peptide. Physiological Reviews 70 665-699.

Donald JA, Toop T \& Evans DH 1994 Localization and analysis of natriuretic peptide receptors in the gills of the toadfish, Opsanus beta (teleostei). American Journal of Physiology 267 R1437-R1444.

Donald JA, Toop T \& Evans DH 1997 Distribution and characterization of natriuretic peptide receptors in the gills of the spiny dogfish, Squalus acanthias. General and Comparative Endocrinology 106 338-347.

Espiner EA 1994 Physiology of natriuretic peptides. Journal of Internal Medicine 235 527-541.

Evans DH 1993 Osmotic and ionic regulation. In The Physiology of Fishes, pp 315-341. Ed DH Evans. Boca Raton: CRC Press.

Gunning M, Cuero C, Solomon R \& Silva P 1993 C-type natriuretic peptide receptors and signaling in rectal gland of Squalus acanthias. American Journal of Physiology 264 F300-F305.

Hagiwara H, Hirose S \& Takei Y 1995 Natriuretic peptides and their receptors. Zoological Science 12 141-149.

Hazon N \& Henderson IW 1985 Factors affecting the secretory dynamics of $1 \alpha$-hydroxycorticosterone in the dogfish, Scyliorhinus canicula. General and Comparative Endocrinology 59 50-55.

Itakura M, Iwashina M, Mizuno T, Ito T, Hagiwara $\mathrm{H} \&$ Hirose $\mathrm{S}$ 1993 Mutational analysis of disulfide bridges in the type C atrial natriuretic peptide receptor. Journal of Biological Chemistry 269 8314-8318.

Kaiya H \& Takei Y 1996 Atrial and ventricular natriuretic peptide concentrations in plasma of freshwater- and seawater-adapted eels. General and Comparative Endocrinology 102 183-190.

Kashiwagi M, Katafuchi T, Kato A, Inuyama H, Ito T, Hagiwara H, Takei Y \& Hirose S 1995 Cloning and properties of a novel natriuretic peptide receptor, NPR-D. European Journal of Biochemistry 233 102-109.

Kloas W \& Hanke W 1992 Effects of atrial natriuretic factor on corticosteroid and catecholamine secretion by the adrenals of Xenopus laevis. General and Comparative Endocrinology 85 269-277.

Kobayashi H \& Takei Y 1996 Biological actions of ANG II. In The Renin-Angiotensin System, pp 114-171. Eds SD Bradshaw, W Burggren, HG Heller, S Ishii, H Langer, G Neuweiler \& DJ Randall. Berlin: Springer-Verlag.

Lihrmann I, Netchitailo P, Feuilloley M, Cantin M, Delarue C, Leboulenger F, De L'an A \& Vaudry H 1988 Effect of atrial natriuretic factor on corticosteroid production by perifused frog interrenal slices. General and Comparative Endocrinology 71 55-62.

Loretz CA 1996 Inhibition of goby posterior intestinal $\mathrm{NaCl}$ absorption by natriuretic peptides and by cardiac extracts. Journal of Comparative Physiology B 166 484-491.

Lowe DG, Camerato TR \& Goeddel DV 1990 cDNA sequence of the human atrial natriuretic peptide clearance receptor. Nucleic Acids Research 183412 .

Maack T, Suzuki M, Almeida A, Nussenzveig D, Scarborough RM, McEnroe GA \& Lewicki JA 1987 Physiological role of silent receptors of atrial natriuretic factor. Science 238 675-678.

Matsushita K, Nishida Y, Hosomi H \& Tanaka S 1991 Effect of atrial natriruetic peptide on water and $\mathrm{NaCl}$ absorption across the intestine. American Journal of Physiology 260 R6-R12.

Mishina S \& Takei Y 1997 Characterisation of natriuretic peptide receptors in eel gill. Journal of Endocrinology 154 415-422.
Munson PJ \& Rodbard D 1980 LIGAND: a versatile computerized approach for the characterization of ligand binding systems. Analytical Biochemistry 107 220-239.

O'Grady SM, Field M, Nash NT \& Rao MC 1985 Atrial natriuretic factor inhibits $\mathrm{Na}-\mathrm{K}-\mathrm{Cl}$ cotransport in teleost intestine. American Journal of Physiology 249 C531-C534.

Ohyama Y, Miyamoto K, Saito Y, Minamino N, Kangawa K \& Matsuo H 1992 Cloning and characterization of two forms of C-type natriuretic peptide receptor in rat brain. Biochemical and Biophysical Research Communication 183 743-749.

Olson KR \& Duff DW 1993 Single-pass gill extraction and tissue distribution of atrial natriuretic peptide in trout. American Journal of Physiology 265 R124-R131.

Racz K, Kuchel O, Cantin M \& De L'an A 1985 Atrial natriuretic factor inhibits the early pathway of steroid biosynthesis in bovine adrenal cortex. FEBS Letters 192 19-22.

Sakaguchi H, Suzuki H, Hagiwara H, Kaiya H, Takei Y, Ito M, Shibabe S \& Hirose S 1996 Whole-body autoradiography and microautoradiography in eels after intra-arterial administration of ${ }^{125}$ I-eel ANP. American Journal of Physiology 271 R926-R935.

Schofield JP, Jones DSC \& Forrest JN Jr 1991 Identification of C-type natriuretic peptide in heart of spiny dogfish shark (Squalus acanthias). American Journal of Physiology 261 F734-F739.

Shimonaka M, Saheki T, Hagiwara H, Ishido M, Nogi A, Fujita T, Wakita K, Inada Y, Kondo J \& Hirose S 1987 Purification of atrial natriuretic peptide receptor from bovine lung: evidence for a disulfide-linked subunit structure. Journal of Biological Chemistry 262 $5510-5514$.

Silva P, Solomon RJ \& Epstein FH 1996 The rectal gland of Squalus acanthias: a model for the transport of chloride. Kidney International 49 1552-1556.

Solomon R, Protter A, McEnroe G, Porter JG \& Silva P 1992 C-type natriuretic peptides stimulate chloride secretion in the rectal gland of Squalus acanthias. American Journal of Physiology 262 R707-R711.

Suzuki R, Takahashi A, Hazon N \& Takei Y 1991 Isolation of high-molecular-weight C-type natriuretic peptide from the heart of a cartilaginous fish (European dogfish, Scyliorhinus canicula). FEBS Letters 282 321-325.

Suzuki R, Togashi K, Ando K \& Takei Y 1994 Distribution and molecular forms of C-type natriuretic peptide in plasma and tissue of a dogfish, Triakis scyllia. General and Comparative Endocrinology 96 378-384.

Takashima A, Katafuchi T, Shibasaki M, Kashiwagi M, Hagiwara H, Takei Y \& Hirose S 1995 Cloning, properties, site-directed mutagenesis analysis of the subunit structure, tissue distribution and regulation of expression of the type- $C$ eel natriuretic peptide receptor. European Journal of Biochemistry 227 673-680.

Tierney M, Takei Y \& Hazon N 1997 Angiotensin II receptors in elasmobranch. General and Comparative Endocrinology 105 9-17.

Watanabe TX, Noda Y, Chino N, Nishiuchi Y, Kimura T, Sakakibara S \& Imai M 1988 Structure--activity relationships of $\alpha$-human atrial natriuretic peptide. European Journal of Pharmacology 147 49-57.

Received 23 May 1997

Revised manuscript received 28 July 1997

Accepted 26 August 1997 